\title{
PHYSICO-CHEMICAL FEATURES OF BIOACTIVE CARBON SORBENTS FOR OIL
}

\author{
Andriy Khokhlov ${ }^{1, *}$, Volodymyr Strelko ${ }^{1}$, Liudmyla Khokhlova ${ }^{1}$
}

https://doi.org/10.23939/chcht12.03.337

\begin{abstract}
The interaction of the hydrophobic carbon sorbents surface and immobilized oil-oxidizing microorganisms when obtaining bio-sorptional complexes of destructive type was studied in this work. The type of sorbent with high oil absorption capacity for immobilization of microorganisms-destructors of oil was selected and justified. Changes in sorbent oil capacity at the immobilization of the bacterial cells were studied.
\end{abstract}

Keywords: carbon sorbent, oleophilic matrix, oil absorption, pyrolysate, structural features, hydrophobicity.

\section{Introduction}

The sorption is one of the most effective and promising methods for cleaning the ecosystems from oil and oil products pollution. The experience of dealing with oil pollutions caused the development of complex technologies with the usage of the new group of substances - biosorbents, which not only have absorption and physico-chemical activity in relation to oil products, but also biological, i.e. the ability to decompose oil by means of biodestruction [1-3]. The new sorbents based on absorption material with immobilized oil-oxidative microorganisms can localize and destroy oil products. The destruction of oil can be executed up to final stages, when only ecologically inert products of oil decomposition remain. The residual part of biosorbent is the primary basis of sorption material. The application of biosorbents is technologically and ecologically effective method for removal of the consequences of accidental oil spills. As the practice showed, biosorbents sometimes can be the only way to fight with accidental oil pollution for different types of environmental objects.

Biosorbents are effective oil absorbing sorbents, which surface is used as a carrier for oil-destructing microorganisms. The development of bioactive sorption materials based on raw materials of natural origin, bio-

\footnotetext{
${ }_{1}^{1}$ Institute for Sorption and Problems of Endoecology NAS of Ukraine,

13, General Naumov St., 03164 Kyiv, Ukraine

techsorb@ukr.net

(c) Khokhlov A., Strelko V., Khokhlova L., 2018
}

activated by a natural complex of oil-oxidative microorganisms with a wide spectrum of action, is a topical task. The effective sorbent-carrier should have the directed adsorption capacity, should meet the requirements to oil absorption sorbents and be biocompatible. Among powder-like sorbents of natural origin, carbon sorbents based on pyrolyzate of cellulosecontaining raw materials have satisfying absorptive capacity in relation to oil and oil products of different composition, and they are biocompatible [4-6].

The adsorption properties of carbon material are determined by a porous structure and chemical nature of the surface. The basic characteristics of porous structure of carbon materials are the volume of pores and their distribution by sizes. These materials have high strength and developed transitive porosity. The establishment of the connection between structural features and sorption properties of the material justifies its usage both as an oil absorbing sorbent and as a carrier for immobilization of oil-oxidative microorganisms at the creation of biodestructive oil sorbents.

\section{Experimental}

Carbon sorbents obtained by pyrolysis of cellulosic materials (wood, corn cobs) under a strictly functional mode were selected as the objects of study. Pyrolysis was carried out in a reactor made of stainless steel with an internal diameter of $60 \mathrm{~mm}$ and a height of $50 \mathrm{~mm}$ with a lid. It was placed in a muffle furnace with automatically regulated power to maintain the desired temperature in the reactor.

The properties of the carbon material surface were evaluated by indicators measured according to the standard methods: specific surface; content of acid and carbonyl groups and regeneration capability. The concentration of the absorbed substance was determined by the weighting, colorimetry and UV-spectrometry methods. Based upon these results the physico-chemical parameters of the pyrolysis process of initial raw materials were calculated and optimal conditions of carbon material synthesis were determined. The sorption properties of 
sorbents were evaluated according to such criteria as floatability, hydrophoby, oil-receptivity and range of working temperatures.

The complex of oil-destructing microorganisms of natural origin was used for the bio-activation of the sorbent. To select strains of oil-destructing microorganisms samples have been collected from the contaminated areas and pure cultures of microorganismsdestructors were obtained which have been grown in a dense nutrient medium. A weighed portion of oil-polluted soil $(100 \mathrm{~g})$ was placed in 1-liter flask with $900 \mathrm{ml}$ of sterile mineral medium and incubated at $303 \mathrm{~K}$. Composition of Raymond's agar medium with oil, g/ $\mathrm{dm}^{3}$ : $\mathrm{Na}_{2} \mathrm{CO}_{3} \quad 0.1 ; \mathrm{CaCl}_{2}$ 0.01; $\mathrm{MnSO}_{4} 0.02 ; \mathrm{FeSO}_{4} \quad 0.01$; $\mathrm{MgSO}_{4}$ 0.2; $\mathrm{NaCl}$ 3.0; $\mathrm{Na}_{2} \mathrm{HPO}_{4} 1.5 ; \mathrm{KH}_{2} \mathrm{PO}_{4}$ 1.0; $\mathrm{KH}_{2} \mathrm{PO}_{4}$ 1.0; agar 20.0; meat-peptone bouillon 500.0; oil $1 \mathrm{~cm}^{3}$; distilled water - the rest up to $1 \mathrm{dm}^{3}$.

After catalase cultivation, the activity was determined in the studied cultures of microorganisms. With its reduction from initial by $30 \%$ or more the studied cultures of microorganisms were selected as active destructors of oil and oil products. This technique allows you to choose microorganisms-destructors that most actively decompose oil and oil products among native microflora. Activity of microorganisms-destructors was determined from Raymond's medium with oil by the degree of degradation of oil (by residual petroleum hydrocarbons using a gravimetric method). Formation and building up of biomass from obtained selected mixed microorganism cultures were carried out in a fermenter with $50 \mathrm{dm}^{3}$ capacity at cultivation parameters, optimal for microorganisms allocation - on liquid mineral medium.

The suspension of the microorganisms-destructors was used for immobilization when the number of microorganisms was declining. Thus, biomass of dry microbial cells in the suspension was not less than $1.0 \mathrm{~g} / \mathrm{dm}^{3}$. Concentration of the biomass was measured gravimetrically by passing the cultural liquid through a membrane filter. Immobilization was carried out in a cylindrical container with heating and with a paddle stirrer. The mixture was thoroughly mixed for even distribution of the carrier and microbial suspension. The adsorption process of the microbial cells on the carrier was controlled by the change of cell concentration (CFU) on the sorbent.

\section{Results and Discussion}

The thermal treatment (pyrolysis) of cellulose containing raw material allows to obtain, form and stabilize a porous structure of the carbon material, and to receive a high volume and high total quantity of meso- and macro-pores, responsible for oil absorption. The temperature and duration of pyrolysis effect the sorption properties of pyrolyzate.

Pyrolysis of the cellulose-containing raw material is based on the decomposition of source material (wood, plant residuals) at heating to certain temperature without air access with the formation of gaseous (liquid) products, as well as solid residuals - coal. The final product of complete raw material pyrolysis is an almost clean carbon, containing potassium, sodium, calcium, magnesium and ferric oxides in the form of minor impurities.

The structural and chemical transformations during pyrolysis of cellulose-containing raw material stipulate the properties of the obtained carbon material. At thermal oxidation of the primary material in the oxygen-free atmosphere the amorphous carbon is formed. The amorphous modification of carbon in the coal from such raw material was proved before [7-8]. If the time of pyrolysis is not enough, the X-ray shows two wide gallos, typical for cellulose with $\max 5.52$ and $3.97 \AA$. The increase of pyrolysis time and temperature over $673 \mathrm{~K}$ leads to destruction of amorphous coal structure, formation of ash, crystallization of inorganic compounds (4.5 ̊́) and decrease of sorption properties of the material.

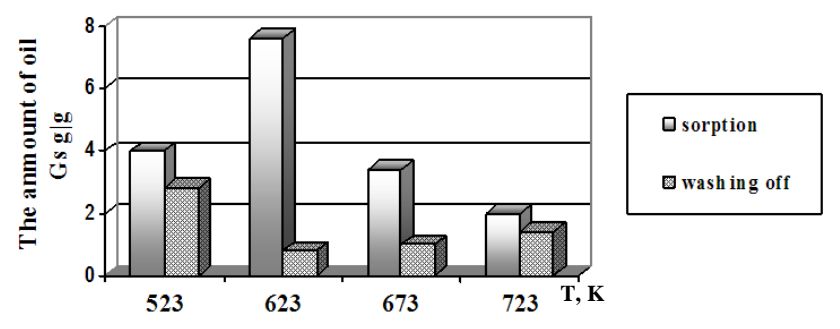

Fig. 1. Influence of pyrolysis temperature on the sorption properties of carbon sorbent

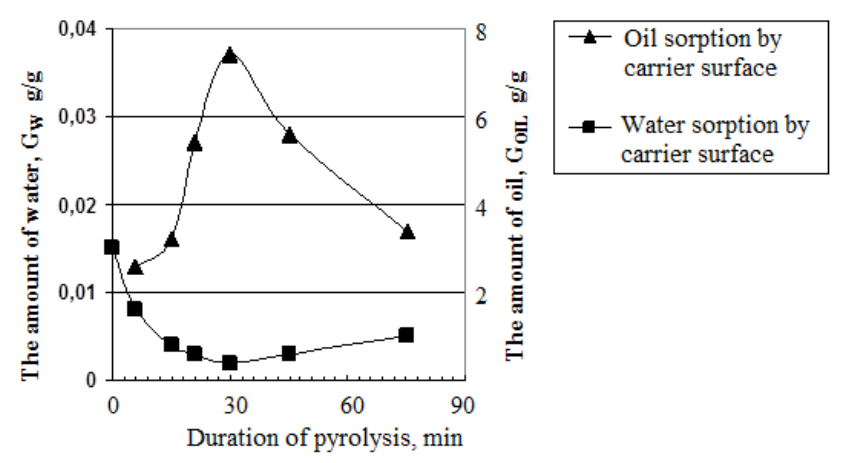

Fig. 2. Influence of pyrolysis duration on oil and water sorption of the carbon material $\left(T_{p}=623 \mathrm{~K}\right)$

The optimal conditions for pyrolysis of intitial raw materials in a laboratory were established for obtaining the carbon material with a high ability to absorb oil, which 
is used as a matrix for immobilization of oil-oxidizing microorganisms. The optimum pyrolysis temperature is $573-623 \mathrm{~K}$, pyrolysis time is $25-30 \mathrm{~min}$. The studies allowed detecting sufficient intermolecular interaction of the sorbent with an adsorbed substance that indicates the possibility to control adsorption properties of carbon material on the production stage. Oil-capacity has extreme dependence on time and temperature of pyrolysis and reaches a value of 5-7.5 g/g. Among powder-like sorbents of natural origin, such sorbents have a satisfying absorptive capacity in relation to oil and oil products of different composition and are biocompatible.

The fraction content of the pyrolyzate also affects the sorption characteristics of carbon sorption matrix. The study of kinetics of absorption and washing the absorbed oil from the surface of carbon material with different disperse content confirmed this dependence. If the fraction with particles diameter less than $0.25 \mathrm{~mm}$ is $30-40 \%$ and prevails in the pyrolyzate and fraction with diameter of $0.25-0.5 \mathrm{~mm}$ is $25-30 \%$ the sorbent has a great retaining capacity in comparison to pyrolyzate, where small fractions (less than $0.25 \mathrm{~mm}$ ) amount is up to $15 \%$. At that, the initial oil capacity of pyrolyzate has equally valuable meaning.

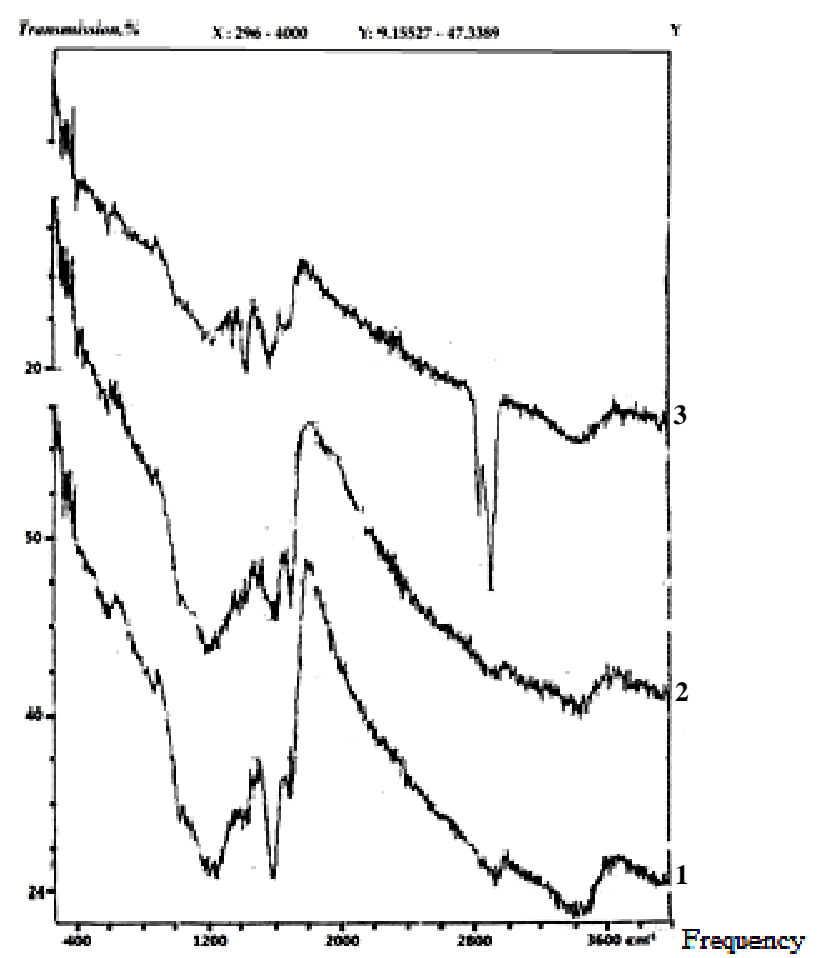

Fig. 3. IR spectra of the initial carbon sorbent (1); bioactivated sorbent (2) and bioactivated sorbent with adsorbed oil (3)

The nature of carbon sorbent surface affects both sorption properties and the possibility and character of immobilization of oil-destructing microorganisms on the sorption material surface. The reactive capable groups are created on the coal surface in the process of formation of carbon material at pyrolysis of cellulose-containing material. The concentration of the functional groups (carboxyl and phenol) on the surface of the carbon material stipulates the ability to retain biomolecules on the surface due to a covalent bond or due to $-\mathrm{COOH}-$, $\mathrm{COCl}-,-\mathrm{NH}_{2}-,-\mathrm{N}^{2+},-\mathrm{NCO}-$ groups [9-10].

IR-spectroscopic studies (Fig. 3) of carbon sorbent showed the reduction of band intensity $\left(1200-1300 \mathrm{~cm}^{-1}\right)$, responsible for fluctuations of phenol groups and band intensity (1700-1750 $\mathrm{cm}^{-1}$ ), typical for carboxyl groups at bioactivation of primary sorption matrix. The surface interaction of sorption matrix with oil destructing biocomplex takes place. This fact confirms the possibility of carbon material usage for obtaining bioactive oil absorbing sorbent of destructive type.

The study of structural characteristics of the initial carbon sorption matrix and bioactivated from different cellulose-containing raw materials (corncobs and wood) showed similar changes in specific surface and quantity of oxygen-containing functional groups. Immobilized biomolecules are held on the carrier surface by Van der Waals forces, hydrogen connections and hydrophobic interactions.

\section{Conclusions}

The criteria of sorption material quality are sorption properties, which were evaluated by oil capacity (the quantity of oil grams absorbed by one gram of sorbent) and holding capacity of the surface relative to the absorbed oil.

The porous structure and chemical nature of the surface of carbon sorption matrix based on pyrolyzate of cellulose containing raw material causes its sorption properties in relation to oil hydrocarbons. However, the dominative factor of oil sorbtion by carbon material is the hydrophobic interaction.

In the phenomena of adsorption, considerable meaning belongs to the intermolecular interaction, where non-polar hydrophobic groups play the main role. The specific features of hydrophobic interaction are explained by the physical nature of the surface.

\section{References}

[1] Lyubin V., Kusainov A., Zakharov I.: Ustranenie Chrezvychainykh Situatsiy pri Razlive Nefti i Nefteproduktov na Vode i na Sushe. Kokshetaus. Techn. Inst., Kokshetau 2014. [2] Shvets D., Khokhlova L., Kravchenko O. et al.: Khimiya i Technol. Vody, 2002, 24, 22.

[3] Altenor S., Carene-Melane B., Gaspard S.: Int. J. Environ. Technol. Manage., 2009, 10, 308. https://doi.org/10.1504/IJETM.2009.023737 
[4] Sidheswaran M., Destaillats H., Sullivan D. et al.: Build.

Environ., 2012, 47, 357.

https://doi.org/10.1016/j.buildenv.2011.07.002

[5] Tancredi N., Cordero T., Rodriguez Mirasol J., Rodriguez J.: Fuel, 1996, 75, 1701. https://doi.org/10.1016/S0016-2361(96)00168-8

[6] Somasundaram S., Sekar K., Gupta V., Ganesan S.: J. Mol. Liq., 2013, 177, 416. https://doi.org/10.1016/j.molliq.2012.09.022

[7] Alcaniz-Monge J., Perez-Cadenas M., Marco-Lozar J.: Adsorpt. Sci. Technol., 2012, 30, 473. https://doi.org/10.1260/0263-

6174.30.6.473

[8] Amutio M., Lopez G., Aguado R. et al.: Energ. Fuel., 2012, 26, 1353. https://doi.org/10.1021/ef201662x

[9] Rincon S., Gomez A.: Global NEST J., 2012, 14, 111.

[10] Alkhatib M., Muyibi S., Amode J.: Environmentalist, 2011, 31, 349. https://doi.org/10.1007/s10669-011-9342-9

Received: July 12, 2017 / Revised: October 23, 2017 / Accepted: December 15, 2017

\section{ФІЗИКО-ХІМІЧНІ ОСОБЛИВОСТІ БІОАКТИВНИХ КАРБОНОВИХ НАФТОСОРБЕНТІВ}

Анотація. Досліджено процес взаємодії поверхні гідрофобних карбонових сорбентів з іммобілізованими нафтоокиснюючими мікроорганізмами при отриманні біосорбційних комплексів деструктивного типу. Вибрано і обтрунтовано тип сорбенту з високою нафтопоглинальною здатністю для іммобілізаиіі мікроорганізмів-деструкторів нафти. Вивчено зміни ємності сорбенту по відноменню до нафти при іммобілізаиії бактеріальних клітин.

Ключові слова: карбоновий сорбент, олеофільна матриця, нафтопоглинання, піролізат, структурні особливості, гідрофобність. 